\title{
ENGLISH WRITING SKILL ANALYSIS OF FIRST YEAR INDONESIAN TERTIARY STUDENTS IN A UNIVERSITY IN BANDUNG
}

\author{
Dian Yuliana, Ernie D. A. Imperiani, \& Eri Kurniawan \\ Department of English Education, FPBS Universitas Pendidikan Indonesia \\ E-mail: dian.yuliana@upi.edu
}

\begin{abstract}
This article reports a study on English writing skill of Indonesian tertiary students. The purpose of the study is to examine students' initial ability in writing English compositions. The subjects of the study are 22 university students in their first year at English Language and Literature study program at one university in Bandung. The data are taken from students' descriptive essays written in the classroom. The texts are then analyzed based on writing rubrics developed by Lane and Lange (1999) to see the recurrent global and local errors, supported by analytic writing rubrics proposed by Jacobs et al. (1981) to see the students' writing ability in general. The results of the study show that the recurrent errors made in twenty-two English descriptive essays are singular/plural nouns for local errors and sentence structure for global errors. In terms of analytic view, errors in language use are the most frequent errors made by the students. The findings provide useful information for constructing teaching materials for English writing in this study program.
\end{abstract}

Keywords: writing skill, descriptive text, composition scoring technique, analytic scoring technique, global and local errors.

\begin{abstract}
Abstrak
Artikel ini melaporkan hasil kajian mengenai keterampilan menulis bahasa Inggris mahasiswa. Tujuan penelitian ini adalah untuk memotret kemampuan awal menulis mahasiswa dalam bahasa Inggris. Adapun subjek penelitian adalah 22 orang mahasiswa tingkat I di Program Studi Bahasa dan Sastra Inggris, di sebuah universitas di Bandung yang dipilih untuk mengetahui kemampuan awal mereka. Data diperoleh melalui karangan deskriptif yang ditulis di kelas.Teks dianalisis dengan menggunakan rubrik penilaian yang dikembangkan oleh Lane and Lange (1999) untuk tataran global dan lokal (global and local errors); dan rubrik penilaian analitik yang dikembangkan oleh Jacobs (1981) untuk melihat keterampilan menulis mahasiswa secara umum. Analisis data menunjukkan bahwa kesalahan yang paling banyak dilakukan mahasiswa pada tataran lokal terkait pemarka nomina tunggal dan jamak (singular/plural nouns), sedangkan pada tataran global, kesalahan pada struktur kalimat (sentence structure) merupakan kesalahan yang paling sering dilakukan oleh mahasiswa. Dari sisi analitik, kesalahan pada penggunaan bahasa merupakan kesalahan yang paling sering ditemukan dalam kebanyakan tulisan mahasiswa.Hasil temuan ini diharapkan dapat memberikan masukan bagi penyusunan bahan ajar matakuliah menulis di lingkungan program studi.
\end{abstract}

Kata kunci: keterampilan menulis, teks deskriptif, teknik penilaian tulisan, teknik penilaian analitik, kesalahan global dan local. 


\section{INTRODUCTION}

It is believed that writing is the most complex and difficult language skill to acquire (Alwasilah, 2004) both in our native language (Martin, 1991; 1993) and in foreign language (Alwasilah, 2004). Writing in a foreign language is even more challenging because it deals with the target language's rules which include grammar and usage rules, vocabulary, and discourse (Hung, 2006) which in most cases are different from those of one's first language. It is important for educators dealing with EFL students' writers to understand the specific problems faced by their students in order to help them improve their writing skills. For this purpose, a baby step to help solve students' problems with writing in a foreign language is the identification and analysis of writing skills of the EFL learners.

With regard to the issue, this present study aims to portray English writing skill of first year Indonesian tertiary students at an English language and literature study program at a state university in Bandung. In particular, this study analyses students' composition in a writing course in the study program. The text analyzed in the study is descriptive text - one of the texts which is discussed in the course.

Descriptive text is a text which deals with the description of a particular thing, a place or a person (Emilia, 2011; Emilia \& Christie (2013). Further they explain that a descriptive text aims to describe or give specific information about things, places or individuals based on their characteristics. In addition, Derewianka (1990 cited in Emilia, 2011) proposes some linguistic features of a descriptive text such as the use of Specific Participants, the use of Descriptive Language, the use of Language to Define, Classify, Compare and Contrast; and the use of some Technical Terms relevant to the things being described.

To assess students' writing in EFL context, there are three major techniques to composition scoring that can be used; namely, holistic scoring, analytical scoring and Primary trait scoring (Weigle, 2002). In addition to these techniques, Lane and
Lange (1999) distinguish global and local errors in composition which can be used as guidelines in editing composition. For this current study, the techniques used are analytical scoring (Jacobs et.al., 1981) and global-local errors (Lane \& Lange, 1999) and hence only these that will be further discussed in the following paragraphs.

Analytical scoring is a scoring technique that uses several criteria for scoring a composition (Weigle, 2002). Jacobs et. al. (1981) proposes a scoring rubric under this technique covering five criteria, namely content, organization, vocabulary, language use and mechanic. The multidimensional aspect of this scoring system is one strength offered by this system as compared to for instance holistic scoring system which presents problems in scoring such as inconsistencies and ineffectiveness for classroom context (Hijikata-Someya, Ono and Yamanishi, 2015), such as that in our case. Details of the scoring rubric s proposed by Jacobs et.al. (1981) used in this study can be seen in Appendix 2.

Another popular rubric that can be used to assess students' writing skill is global and local errors developed by Lane and Lange (1999). They developed the rubric as a guideline for editing students' compositions. They refer to global errors as more serious errors which interfere with the readers' ability to understand the entire sentence/paragraph within a piece of writing. These cover incorrect verb tense, incorrect verb forms, incorrect use or formation of modals, incorrect use or formation of conditional sentences, incorrect or awkward word order, incorrect or missing connector, incorrect formation or use of passive voice and unclear message (p. xx). On the other hand, local errors are defined as less serious and do not alter the meaning of the sentence and thus not affecting readers' understanding of the text. These cover incorrect subject-verb agreement, incorrect or missing article, problem with the singular or plural of a noun, wrong word choice, including preposition, wrong word form and non- 
idiomatic expressions (p. xxi). The criteria for identifying these two types of errors can be seen in table 1 below.

Table 1: Global and Local Error (Lane \& Lange, 1999)

\begin{tabular}{|c|c|}
\hline Global Errors & Local Errors \\
\hline Incorrect verb tense & incorrect subject-verb agreement \\
\hline incorrect verb forms & incorrect or missing article \\
\hline incorrect use or formation of modals & $\begin{array}{l}\text { problem with the singular or plural of a } \\
\text { noun }\end{array}$ \\
\hline $\begin{array}{l}\text { incorrect use or formation of } \\
\text { conditional sentences }\end{array}$ & $\begin{array}{l}\text { wrong word choice including } \\
\text { preposition }\end{array}$ \\
\hline incorrect or awkward word order & $\begin{array}{l}\text { wrong word form and non-idiomatic } \\
\text { expressions }\end{array}$ \\
\hline \multicolumn{2}{|l|}{ incorrect or missing connector } \\
\hline \multicolumn{2}{|l|}{$\begin{array}{l}\text { incorrect formation or use of passive } \\
\text { voice }\end{array}$} \\
\hline unclear message & \\
\hline
\end{tabular}

There have been numerous studies examining students' writing that incorporated analytic scoring and global and local errors' rubric. One study conducted by Reyhan (2012), for example, used Jacobs et.al's (1981) analytic scoring to examine whether the use of guided writing and sequences of pictures as teaching techniques can enhance the students'writing ability. It was discovered that guided writing and sequences of pictures can improve the students' writing ability. Moreover, Reyhan in the study also admits that the use of analytic scoring is more efficient than any other scorings like holistic scoring to analyze the students' writing improvement. Regarding global and local errors, Mony (2005), for instance, investigated the errors made by tertiary students in a college in Cambodia. Using Lane and Lange's (1999) global and local errors' rubric, it was found that four most frequent errors made by the students in the study were verb tenses, verb forms, subject-verb agreement and modals. A study that incorporated both scoring systems such as that conducted by White (1988) had similar purpose as that of Reyhan's study to see improvement in essays written by Indonesian graduate students attending a course in English for Academic Program over an eight week period. Drawing on Brown and Bailey's (1980 cited in White, 1988) analytical scoring device and Carlman's (1984 cited in White, 1988)) global scoring device, the study found that students' writing improved particularly in the areas of logic and organization style; while improvements in grammar, punctuation and mechanics were not significant. Another study in this area was conducted by Izadpanah, et. al. (2014) who investigated the possible interplay between holistic and analytic scoring sytems in rating second language writing and whether or not these systems underestimate or overestimate the scores in comparison to each other. The study indicated that the scales of the two writing scoring systems were successful predictor of each other. It was also found that the analytical writing score underestimated the writing ability of the lower-level participants - the scores of the mid and high levels were consistent according to two rating scales.

As discussed previously, the superiority of analytic scoring to holistic scoring has been attested to by studies analysing students' writing (among others 
Hijikata-Someya, Ono and Yamanishi (2015); and Reyhan(2012); Soleymanzadeh and Gholami (2014). However,studies examining students' compositions employing analytic scoring device as discussed in the previous paragraph are mostly comparative in nature in which they compared analytic scoring system to other systems as exemplified in Izadpanahet.al's study above. As indicated in other previous works on error analysis of students' composition (e.g. Lane and Lange, 1999; White, 1988), the rubrics of global and local errors are beneficial for providing a more detailed and comprehensive analysis of errors and their effects on the text's readability. This benefit is especially important for teachers commenting on students' writing so that students can improve their text better. Even though there are relatively many studies analyzing students' writing using global and local error rubrics, studies that used such scoring rubrics in conjunction with analytic scoring are still few -- while it is believed that the combination of the two scoring devices in analyzing students' composition will provide stronger results.

This present study is accordingly conducted to fill this gap, i.e. to analyze students' compositions to portray their initial writing skills using analytic scoring and global and local error rubrics. For this purpose, Jacobs et. al's. (1981) analytic scoring and Lane and Lange's (1999) local and global error rubrics for editing guidelines are used. It is expected that the results of this study will provide useful information to construct teaching materials for first year English writing course in this study program.

\section{METHOD}

This study employed a descriptive qualitative design aimed at examining the students' initial ability in writing English composition. The data of this research were gathered from the samples of 22 students' descriptive essays on the topic of hometown, with the length of about 250 words. The texts were written in the classroom. The students in this study were first year students who enrolled in Writing for General Communication 1 course at English Language and Literature study program at one university in Bandung. In the findings and discussion section of this paper, the students will be referred to as Student 1 - Student 22. The reason for choosing the first year students in this research is due to the main purpose of this study which is to know the initial writing proficiency level of the first year students of the study program to assess their knowledge and competence in writing. This information will be the basis for constructing teaching materials for first year English writing course in this study program.

To maintain the validity of the study,there were three raters involved in evaluating the students' descriptive essays. All the three raters were Indonesian lecturers who had a TESOL background. The selected three raters were then asked to evaluate the 22 students' essays by using the analytic writing rubrics proposed by Jacobs et.al. (1981) to see students' writing ability in general. To see the global and local errors in students' texts, the data were also analyzed using editing guidelines developed by Lane and Lange (1999), with some modification -see the modified rubric in Table 2 below. To rate the students' essays using this rubric, the raters identified the frequency of each type of errors found in the essays and then calculated the total occurrences. 
Table 2: Modified Editing Guidelines for Local and Global Errors

\begin{tabular}{ll}
\hline Global Errors & Local Errors \\
\hline Incorrect verb tense & Incorrect subject-verb agreement \\
\hline Incorrect verb form & Incorrect or missing article \\
\hline Incorrect form or use of a modal & Problem with the singular or plural of a noun \\
\hline Incorrect form or use of conditional sentences & Wrong word choice \\
\hline Incorrect form or use of passive voice & Wrong word form \\
\hline Incorrect sentence structures & Prepositions \\
\hline
\end{tabular}

Incorrect or awkward word order

Incorrect or missing connectors

The evaluations from the three raters were then combined to see the average score for each scoring system which was later used to determine students' level of writing proficiency. With regard to Jacobs et. al's (1981) analytic scoring, the average score of the three raters on each criteria for each student was then matched to the composition profile suggested in the scoring system, either excellent to very good, good to average, fair to poor or very poor. Meanwhile, the average score obtained from Lane and Lange's (1999) the global and local error rubrics was used to identify the frequency of errors the students made in their text, and whether they belonged to global or local type. The results of from these two step-analyses were then combined to see connections and to draw the conclusions regarding the level of writing proficiency of the students in this study.

\section{FINDINGS AND DISCUSSION}

\section{Students' Composition Profile: Analytic}

The analysis using Jacob's et. al. (1981) analytic scoring showed that in general the students' writing skill is at the level of Good to Average, as can be seen in Table 3.

\section{Table 3: Students' Analytic Composition Profile}

\begin{tabular}{|c|c|c|c|c|c|c|c|}
\hline $\begin{array}{l}\text { Aspects of } \\
\text { Writing }\end{array}$ & Content & & Organization & Vocabulary & & $\begin{array}{l}\text { Language } \\
\text { Use }\end{array}$ & $\begin{array}{l}\text { Mechanic } \\
s\end{array}$ \\
\hline Average & 22.3 & & 14.7 & 15 & & 15.9 & 3.6 \\
\hline Level & $\begin{array}{l}\text { Good } \\
\text { Average }\end{array}$ & to & $\begin{array}{l}\text { Good } \\
\text { Average }\end{array}$ & $\begin{array}{l}\text { Good } \\
\text { Average }\end{array}$ & to & Fair to Poor & $\begin{array}{l}\text { Fair } \\
\text { Poor }\end{array}$ \\
\hline
\end{tabular}

As shown in Table 3, three out of five aspects of students' composition are at the level of Good to Average. These aspects are Content (22.3), Organization (14.7) and Vocabulary (15). From these three aspects, the students performed best in Vocabulary (15) because, unlike the other two aspects, the average score they gained on Vocabulary was not within the minimum score range (see Appendix 2 for details of scoring range for each writing skill level).

It was found that students' vocabulary in this study contains linguistic 
features of a descriptive text as proposed by Derewianka (1990, cited in Emilia, 2011) and Emilia and Christie (2013), namely the use of Specific Participants, the use of Descriptive Language, the use of Language to Define, Classify, Compare and Contrast; and the use of some Technical Terms relevant to the things being described.
All the students use Specific Participants in their texts in a specific way to refer to the thing being described, as can be seen in Excerpts 1 to 3 below (specific participants are underlined; asterisk indicates errors in grammar, spelling and sentence structures - the revised version is in square brackets).

E1. Bandung is the capital city of West Java ..... (Student 6)

E2. Jakarta is a small city but this city always *affected another city in Indonesia. (Student 7) [Jakarta is a small city but this city always *affects other cities in Indonesia.]

E3. Another thing that I can't forget from my village is "Gandoriah Beach" (Student 20)

The Specific Participants Bandung, West Java, Jakarta, my village and Gandoriah Beach in Excerpts 1 to 3 above tell the reader about the particular place that the writers of the texts want to identify and describe.

In addition to Specific Participants, the students also used Descriptive Language - another language feature of a good descriptive text as argued by Derewianka
(1990, cited in Emilia, 2011) and Emilia and Christie (2013) to describe the place or things related to hometown. Some examples of the use of descriptive language in students' texts can be seen in Excerpts 4 to 6 below (descriptive language is underlined; asterisk indicates errors in grammar, spelling and sentence structures the revised versions are in square brackets).

E4. Even though it's a market, but it's very clean and ${ }^{*}$ free nasty [free of nasty] smell. (Student 8 )

E5. *If lovely means beautiful scenery, breath-taking views, crystal clear river with fish, lovely fish, swimming in it. No, my hometown will be far from lovely. (Student 18)

If lovely means beautiful scenery, breath-taking views, and crystal clear rivers with fish, lovely fish, swimming in them -- no, my hometown will be far from lovely]

E6. You can find many restaurants that served not only local food but also international food. (Student 4)

The underlined words/phrases very clean, free (of) nasty, beautiful, breath-taking, crystal clear, lovely in Excerpts $4-6$ above give more description of the things mentioned in the respected sentences by attaching attributes/qualities to them. Attaching qualities to the things being described give clearer description. For example, if the noun phrases containing descriptive language in Excerpt 4 written by Student 8 are omitted from the sentence, the meaning of the sentence would be hanging and the description of the market would be unclear *Even though it's a market, but it's and smell.
This example shows the importance of descriptive language in a descriptive text.

Another linguistic feature of descriptive text found in students' texts as proposed by Derewianka (1990, cited in Emilia, 2011) and Emilia and Christie (2013) is the use of language to define, classify, compare and contrast. This feature is exemplified in Excerpts $7-10$ below (language to define, classify, compare and contrast is underlined; asterisk indicates errors in grammar, spelling and sentence structures - the revised versions in square brackets).

E7. Pekanbaruis also called as 'Oil City'. (Student 8)

E8. * Unlike the other transportation in another city. The owner of the PT decorated their car become like a lux car. (Student 20)

[Unlike other public transportations in other city, the owner of the PTs in Padang decorate their cars like those of lux cars] 
E9. And the fresh air in Garut is as fresh as *Switzerland. (Student 21)

[And the fresh air in Garut is as fresh as that in Switzerland]

E10. Bandung is considered a paradise by many people who *visits [visit] it. (Student 4)

As can be seen in E7, Student 8 uses the phrase is also called as to define the city of Pekanbaru. Meanwhile, in Excerpt 8 Student 20 uses the word unlike to contrast the condition of public transportation in Padang to that in other cities in Indonesia. In addition, Student 21 demonstrates in Excerpt 9 how she compares the fresh air in Garut to that in Switzerland. Furthermore in E10, Student 4 uses the verb phrase is considered to classify Bandung as a paradise to many people who visit the city.

Finally, the last linguistic feature of descriptive text related to vocabulary demonstrated by the students in their texts is the use of technical terms relevant to the things being described, in this case hometown, which can be seen in Excerpts 11-12 below (technical terms underlined).

E11. I was born in a village called MargaAsihPermai. (Student 19)

E12. I was born in a marvelous little city near Bandung named Cimahi. (Student 11)

As can be seen in Excerpts 11 and 12 above, the use of a village and a marvelous little city are technical terms related to hometown. As discussed in Derewianka (1990, cited in Emilia, 2011), a descriptive text may use some technical terms -- which means, in Derewianka's view, that this feature is actually optional. The analysis on students' texts revealed that there were not many technical terms in their texts. Some recurring technical terms found in the data are village, city - as exemplified in the excerpts above - town, and countryside.

In addition to Vocabulary, the next aspect in analytical scoring profile is Content. The students' average score for this criterion is 22.3, with the level of Good to Average. The students obtained the level because the theme in their texts is in line with the theme assigned, which is about hometown. This theme can be seen for instance from the titles of the texts (see Appendix 1 for the complete titles of the students' texts). The purpose of the text which is the description of hometown is made clear in the titles of most texts, such as Bandung (written by Students 1, 2 and 10), Bandung a Paradise for many People (written by Student 4), and Bandung Lovely Town (written by Student 13). The purpose of the text however is not quite explicit in two titles, namely All you Need in One Place (Written by Student 6) and Little but not Little (Written by Student 11). Also, two students, Student 5 and Student 8, did not give titles to their texts, hence giving no information about the content of the texts.

Besides the title, the vocabulary used by the students in their writing also reflects the content of the text which describes their hometown, as has been presented in the discussion of vocabulary (see Excerpts 1-12 above).

The next scoring criterion in analytical scoring technique is Organization, in which the average of the students gained the level of Good to Average with the score of 14.7. This composition profile was given because in general the students in this study could organize their essays into opening, body, and closing. This ability indicates a good organization skill which has also been demonstrated in essays written by Indonesian graduate students who participated in White's (1988) study. In addition, albeit not explicitly stated in the form of clear topic sentence, most students' texts are developed following one main idea which is in accordance with the description of Jacobs et.al's (1981) students' composition profile in terms of organization for the level of Good to Average. For instance, Student 11 who wrote the text entitled Little but not Little, developed her text using the main idea of the hidden potential in her little hometown. Another student, Student 5, developed his text 
around the main idea of good things about his hometown.

Despite the relatively good level of organization displayed by most students in this study, a few of them demonstrated problems in organizing their texts well. One example is given in Table 4 below.

\section{Table 4: Organization - Excerpt from Student 5}

1. If you looking for local food as a gift for your family, dodol is the most famous Garut local food. 2. Garut also famous of its leather product, like bags, jacket, shoes. 3. The centre of all leather product in Garut is Sukaregang. 4. You can find many traditional foods at Ceplak street. 5. There are many food seller in that street. 6. Garut is a lovely city from its many beautiful places.

Table 4 above shows that Student 5 performs poorly in organizing his paragraph. Rather than focusing on finishing his description of local food in Garut in the first three sentences (sentences 1 - 3), he describes leather product in sentences 2 and 3 and continues the description of traditional food in sentences 4 and 5 , making the organization of his idea disconnected. This disconnectedness of ideas is also apparent in his concluding sentence (sentence 6) about beautiful places in Garut which is irrelevant to the discussion in the paragraph about local food and leather.

The last two criteria in analytical scoring techniques are Language Use and Mechanics. Students' levels at these two subsets are Fair to Poor with the score of 15.9 and 3.6 respectively. In terms of Language Use, this level was due to relatively many occurrences of inappropriate sentence structures that cover problems in word order, subject verb agreement, tenses, articles, pronouns, prepositions, fragments or run-ons, and meaning confused. Detailed discussion on each of these problems can be seen in students' composition profile of global and local errors in Sections 1 and 2 below.

Regarding mechanics, it was found that students often made mistakes in spelling, punctuation, and capitalization. No instance of paragraphing problem was found in the data. The examples of problems in spelling, punctuation and capitalization are shown in Excerpts 13 - 15 below (problems in spelling, punctuation, and capitalization are underlined; error verb forms in asterisk, the correct form in square brackets).

E13. If that promblem $*$ can solve [can be solved] immidietlly...(Student 13)

E14. But this time we don't have to *be panic [panic] because._now Jakarta is getting clean and comfortable. (Student 7)

E15. it isn't look like a village though, it look like a small real-estate where.... (Student 19)

As can be seen in Excerpt 13, Student 13 misspelled the word problem as promblem, and immediately as immediately. Punctuation problem is demonstrated by Student 7 in Excerpt 14, where colon is not necessary in the sentence. Moreover, Student 19 made problem with capitalization in Excerpt 15, where the letter $i$ in the word $i$, which is the first word in the sentence should be capitalized.

This section has demonstrated the findings of the error analysis on students' composition using Jacobs et.al's (1981 cited in Weigle 2002) analytic scoring system which shows that in general the participants' proficiency in writing are at the level of good to average. Despite positive reviews from researchers working in the area of writing evaluation; among others HijikataSomeya et.al (2015), Reyhan (2012), and Soleymanzadeh and Gholami (2014), other researchers such as Ghanbari et.al (2012) believe that this system is not quite suitable for EFL contexts. In addition, Izadpanah et.al (2014) also admit that this scoring system underestimates the writing ability of 
the lower level students. Therefore, these issues may interfere with the overall findings regarding the use of this scoring system for data analysis.

\section{Students' Composition Profile: Global and Local Errors}

The findings from the data analysis indicated that all errors under Lane and Lange's (1999) global and local errors are found in students' writing. These are presented in Table 5 below.

Table 5: The Average of Global and Local Errors in Students' Texts

\begin{tabular}{|c|c|c|c|c|c|c|c|c|c|c|c|c|c|}
\hline \multicolumn{8}{|c|}{ GLOBAL } & \multicolumn{6}{|c|}{ LOCAL } \\
\hline Tns. & Mod. & Cond. & Pasv & Cl. & SS & WO & $\mathrm{CW}$ & SVA & Art. & P1. & Dict. & WF & Prep. \\
\hline 24.00 & 9.00 & 2.00 & 22.67 & 4.67 & 72.00 & 1.33 & 4.67 & 43.00 & 53.33 & 92.67 & 46.00 & 55.00 & 19.67 \\
\hline
\end{tabular}

From the table above, it can be seen that the most frequent errors evident in students' writing from each category are sentence structure for global error and plural/singular noun for local error. On the other hand, the least frequent errors found in the data are word order for global error and preposition for local error. More detailed discussion on global and local errors found in students' texts is given below.

\section{Global Errors}

As indicated in Table 5 above, the most frequent error students made in global error is sentence structure. This error is exemplified in Excerpts $16-18$ below.

E16. The most iconic one from Garut. (Student 21)

E17. One thing it make me love my hometown is the people there. (Student 2)

E18. The people who visited KebunBinatang usually they are eats together there. (Student 1)

From the excerpts above, it can be seen how errors in sentence structures create confusion in understanding the message of the sentence and make the structure incorrect. In E16, Student 21 misses the verb of the "sentence", making it a fragment and obscuring the meaning. Similarly, the use of the pronoun it in Excerpt E18 obscures the message of the sentence, which could have been avoided by the use of relative pronoun that i.e. One thing that make me love my hometown is the people there. The use of theyin E18 unnecessarily repeats the subject the people, making the sentence incorrect.
The finding of the present study with regards to errors in sentence structure is in contrast with that conducted by Satariyan and Mohseni (2014) who investigated common errors in the writing of the first year students of Azad University in Iran. Errors in sentence structure were among the least frequent errors made by the students.

Other common errors are related to tenses and passives. The examples of these errors are presented and underlined in Excerpts 19-22 below.

E19. Foods and Drinks in Bandung are *very [very] unique, like "Leupeut" -- Leupeut is a traditional food from Bandung that *peoples [people] loved. (Student 2)

E20. Jakarta is a small city but this city always affected another city in Indonesia. (Student 7)

E21. *For all student [all students] from junior high school until senior high school (for young

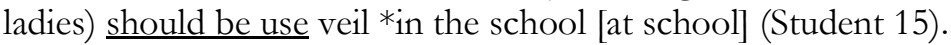

E22. The Dam Project placed in Jatigede. (Student 16). 
In Excerpts 19 and 20 Students 2 and 7 make errors in tenses. The use of the simple past form of love, loved, in E19 and the simple past form of affect, affected, in E20 are not appropriate considering the two excerpts present factual facts about food and drink in Bandung and Jakarta in relation to other cities in Indonesia. In these two excerpts, the simple present forms should be used instead. These errors in tenses commonly happen in EFL writing as indicated in Mony's (2005) and Cabansag's (2013) study.

Meanwhile, excerpt 21 and 22 demonstrate students' errors in passives. In
E21, for instance, the use of passive form verb should be use should be written in the active form like For all student from junior high school until senior high school (for young ladies) should use veil in the school to make the sentence more appropriate. This also applies to Excerpt 22 where the verb place should be made passive.

Furthermore, the least frequent errors are word order and conditional sentences, which are exemplified in Excerpts 23 and 24 (errors in these areas are underlined).

E23. ... Taman LaluLintas is the one of favorite *place that the children want to go. (Student 1)

E24. If I had problem, I just go to this beach and throw some things like wood, stones or may be bottles. (Student 20)

As can be seen in Excerpt 23, Student 1 demonstrated error in word order in which the article the incorrectly precedes the phrase one of; whereas the more proper order for this phrase would be one of the. On the other hand, Excerpt 24 presents incorrect use of a conditional sentence. Only few occurrences of conditional sentences found in the data and thus the little frequency of error of this type of sentence may not be due to students' mastery in this sentence type but may be due to the limited data found in the text. The sentence in Excerpt 24 is type 1 conditional but the first clause of the sentence If I had problem is not appropriate for this type, the appropriate one of would be If I have problem.

\section{Local Errors}

As indicated in Table 5, the most frequent errors found in students' writing under the category of local errors are problems with the singular or plural of a noun and incorrect or missing articles. Excerpts 25-28 exemplify these errors (errors in these areas are underlined).

E25. The floor of the car *also covered [is also covered] by ceramics or some of them are glass. (Student 20)

E26. There are a lot of shopping centre that offers their goods with high quality, yet they also offer their high quality goods with low price. (Student 6)

E27. Bandung has a many problems such as the air *pollution [pollution], traffic jam, transportation, and broken roads. (Student 13)

E28. But then I studied at school *that place [that is located] in centre of city. (Student 12)

From the excerpts above, it can be seen that some students in the study are still confused about the correct use of singular and plural form as well as articles. In Excerpt 25, Student 20 incorrectly uses glass instead of glasses for the plural form. Similarly, Student 6 mistakenly uses the singular form centrefor the plural expression centres which agree with the verb are. Meanwhile, Students 13 and 12 show non-mastery in article use as can be seen in Excerpts 27 and 28. Student 13 uses indefinite article $a$ before the plural nounphrase many problems where such article is not needed. In contrast, Student 12 misses the definite article the before centre andcity. 
Had this student used the article properly, the phrase would be in the centre of the city.

Finally, the least frequent error under the category of local errors found in the data is preposition as can be seen in Excerpts 29-30 below (error is underlined).

E29. Near of the government office there is a mosque... (Student 14)

E30. Probably because my hometown is a village, so the people there $*_{\text {is }}$ [are] still caring each other. (Student 3)

The two excerpts above indicate the incorrect use or the missing of preposition. Excerpt 29 shows the incorrect use of the preposition of following the preposition near which does not require another preposition. Unlike Excerpt 29, Excerpt 30 lacks the preposition for required for following the verb caring.

\section{CONCLUSION}

This study aimed to investigate the initial writing proficiency level of the first year students majoring in English Language and Literature in a university in Bandung. In particular, it has main purpose to assess students' knowledge and competence in writing for constructing teaching materials for first year English writing course in this study program. The results of the study revealed that analytically, students in average are at the level of Good to Average in the areas of Vocabulary, Content and Organization, and Fair to Poor in the areas of Language Use and Mechanics. Meanwhile, from Global error, it can be concluded that students made error most frequently in Sentence Structure and least frequently in Word Order. Whereas, from Local error, it was found that the error the student most frequently made is problems with the singular/plural of a noun. Finally, the least recurrent error in Local error is Prepositions. To improve the validity of the raters, rater severity should be tested, for instance by using multifaceted Rasch Analysis (MFRA, see for instance Meier, 2012). For researchers interested to conduct studies in assessing students' writing using Jacobs et.al (1981) scoring system may wish to use the modified version as that developed by Reyhan (2012) to enhance its suitability with EFL contexts.It is also expected that the findings of the study would provide a new insightinto the construction of teaching materials for first year English writing course in Indonesian tertiary education context.

\section{REFERENCES}

Alwasilah, A. C. (2004). Improving Writing Skills through Collaborative Learning.In B. Y. Cahyono\& U. Widiati (Eds.).The Tapestry of English Language Teaching and Learning in Indonesia. pp. 99 - 109. Malang: State University of Malang Press.

Cabansag, J. N. (2013). Written Langugae Proficiency of Laboratory High School Students in a State University in Cagayan Valley Phillipines. Reearchers World-Journal of Arts, Science \& Commerce Vol. IV(2). Pp. 87-93.

Emilia, E. (2011). Pendekatan genre-based dalampengajaranbahasaInggris: Petunjukuntuk guru. Bandung: Rizqi Press

Emilia, E. \& Christie, F. (2013).Factual genres in English: Learning to write, read and talk about factual information. Bandung: Rizqi Press

Lane, J. \& Lange, E. (1999).Writing clearly: An editing guide. Boston: Heinle\&Heinle Publishers.

Ghanbari, B., Barati, H., and Moinzadeh, A. (2012). Rating Scales Revisited: EFL Writing Assessment Context of Iran under Scrutiny. Language Testing in Asia, vol. 2(1), pp. 83-100.

Hijikata-Someya, Y., Ono, M., and Yamanishi, H. (2015). Evaluation by Native and Non-Native EnglishTeacher Raters of Japanese 
Students' Summaries. English Language Teaching, vol. 8 (7).

Hung, F S. (2006). Improving written accuracy through grammar instruction and error correction.Journal of Applied Foreign Languages, vol.6, pp. 1-23.

Izadpanah, M.A., Rakhshandehroo, F., Hoomanfard, H. M., and Mahmoudikia, M. (2014). On the Consensus Between Holistic Rating System and Analytic Rating System: A Comparison betwen TOEFL IBT and Jacobs et. al. Composition Profile. International Journal of Language Learning and Applied Linguistic World, vol 6(1), pp. 170187.

Jacobs, H. L., Stephen, A., Zingkgraf, D. R., Wormuth, V., Faye, H., Jane, B., and Hughey. (1981). Testing ESL Composition: A Practical Approach. Rowley: Newbury House Publishers, Inc.

Martin, J. R. (1991). Nominalization in science and humanities: Distilling knowledge and scaffolding text. In E. Ventola (Ed.) Trends in Linguistics: Studies and Monograph 55.pp. 307-338. The Hague: Mouton de Gruyter.

Martin, J. R. (1993). Technicality and abstraction: language for the creating of specialized texts. In M. A. K. Halliday\& J. R. Martin (Eds).Writing in Science. pp. 203-220. London: The Falmer Press.

Meier, V. (2012). Evaluating Rater and Rubric Performance on a Writing Placement Exam. In Second Language Studies, 31(1), pp. 47-101

Mony, S. (2005).Error Analysis on the use of verbs in English Compositions Written by
Students at the National Institute of Education, Phnom Penh, Cambodia.Unpublished Thesis, UniversitiPendidikan Sultan Idris, Malaysia.

Reyhan, A. (2012). The Use of Guided Writing and Sequences of Pictures as Teaching Techniques to Enhance the Ability of Writing Narrative of Students in "Different English Course". Anglicist, vol 01(2), 1-6.

Satariyan, A. \& Mohseni, A. (2014). Writing Skill and Categorical Error Analysis: a Study of First Year Undergraduate University Students. Iranian Journal of Research in English Language Teaching, vol. 1(3), pp. 20-30

Soleymanzadeh, L., \& Gholami, J. (2014). Scoring Argumentative Essays Based on Thematic Progression Patterns and IELTS Analytic Scorign Criteria. Procedia - Social and Behavioral Sciences, 98 (2014), pp. 1811-1819

Weigle, S. C. (2002). Assessing writing. Cambridge: Cambridge University Press

White, M.J. (1988). An Analysis of the Academic Writing of Indonesian Graduate Students at Simon Fraser University. Unpublished Thesis, Simon Fraser University.

\section{ACKNOWLEDGEMENTS}

We would like to sincerely extend our greatest gratitude to Jurnal Pendidikan Bahasa dan Sastra for publishing this article. Our highest appreciation also goes to those who have helped the whole process of writing and publishing this article. 


\section{APPENDICES}

\section{Appendix 1. Titles of the Texts Written by the Students}

\begin{tabular}{|c|c|}
\hline Students & Title \\
\hline 1 & Bandung \\
\hline 2 & Bandung \\
\hline 3 & Subang is my Hometown \\
\hline 4 & Bandung a Paradise for many People \\
\hline 5 & - \\
\hline 6 & All you Need in One Place \\
\hline 7 & Jakarta \\
\hline 8 & - \\
\hline 9 & The Beauty of Bandung \\
\hline 10 & Bandung \\
\hline 11 & Little but not Little \\
\hline 12 & Bandung, my Hometown \\
\hline 13 & Bandung Lovely Town \\
\hline 14 & A Splendid Town \\
\hline 15 & My Lovely City \\
\hline 16 & Sumedang \\
\hline 17 & The Flower City \\
\hline 18 & My Lovely Hometown \\
\hline 19 & Hometown, You are Lovely, Are You not? \\
\hline 20 & My Lovely and *Beauty [Beautiful] Hometown \\
\hline 21 & My Lovely Hometown \\
\hline 22 & A Paradise in Swiss van Java \\
\hline
\end{tabular}


Appendix 2. ESL Composition Analytic Scoring Profile (Jacobs et al.'S(1980)

\section{CONTENT}

\begin{tabular}{|l|l|}
\hline Score & Criteria \\
\hline $30-27$ & $\begin{array}{l}\text { EXCELLENT TO VERY GOOD: knowledgeable; substantive; thorough development of } \\
\text { thesis; relevant to assigned topic }\end{array}$ \\
\hline $26-22$ & $\begin{array}{l}\text { GOOD TO AVERAGE: some knowledge of subject; adequate range; limited development of } \\
\text { thesis; mostly relevant to topic, but lacks detail }\end{array}$ \\
\hline $21-17$ & $\begin{array}{l}\text { FAIR TO POOR: limited knowledge of subject; little substance; inadequate development of } \\
\text { topic }\end{array}$ \\
\hline $16-13$ & $\begin{array}{l}\text { VERY POOR: does not know knowledge of subject, non-substantive; not pertinent; OR not } \\
\text { enough to evaluate }\end{array}$ \\
\hline
\end{tabular}

\section{ORGANIZATION}

\begin{tabular}{|l|l|}
\hline Score & Criteria \\
\hline $20-18$ & $\begin{array}{l}\text { EXCELLENT TO VERY GOOD: fluent expression; idea clearly stated/supported; succint, } \\
\text { well-organized; logical sequencing; cohesive }\end{array}$ \\
\hline $17-14$ & $\begin{array}{l}\text { GOOD TO AVERAGE: somewhat choppy; loosely organized but main idea stand out; limited } \\
\text { support; logical but incomplete sequencing }\end{array}$ \\
\hline $13-10$ & $\begin{array}{l}\text { FAIR TO POOR: non-fluent; ideas confused or disconnected; lacks logical sequencing and } \\
\text { development }\end{array}$ \\
\hline $9-7$ & VERY POOR: does not communicate; no organization; OR not enough to evaluate \\
\hline
\end{tabular}

\section{VOCABULARY}

\begin{tabular}{|l|l|}
\hline Score & Criteria \\
\hline 20-18 & $\begin{array}{l}\text { EXCELLENT TO VERY GOOD: sophisticatd range; effective word/idiom choice and usage, } \\
\text { word form mastery; appropriate register }\end{array}$ \\
\hline $17-14$ & $\begin{array}{l}\text { GOOD TO AVERAGE: adequate range; occasional occasional errors of word/idiom form, } \\
\text { choice, usage but meaning not obscured }\end{array}$ \\
\hline $13-10$ & $\begin{array}{l}\text { FAIR TO POOR: Limited range, frequent errors of word/idiom form, choice, usage, meaning } \\
\text { confused or obscured }\end{array}$ \\
\hline $9-7$ & $\begin{array}{l}\text { VERY POOR: essentially translation; little knowledge of English vocabulary, idioms, word } \\
\text { form; OR not enough to evaluate }\end{array}$ \\
\hline
\end{tabular}




\section{LANGUAGE USE}

\begin{tabular}{|l|l|}
\hline Score & Criteria \\
\hline 25-22 & $\begin{array}{l}\text { EXCELLENT TO VERY GOOD:effective complex construction; few errors of aggreement, } \\
\text { tense, number, word order/function, prepositions, articles, pronouns }\end{array}$ \\
\hline 21-18 & $\begin{array}{l}\text { GOOD TO AVERAGE: effective but simple constructions; minor porblmes in complex } \\
\text { constructions; several errors of agreement, tense, number, word order/functions, articles, } \\
\text { pronouns, prepositions but meaning seldom obscured }\end{array}$ \\
\hline $17-11$ & $\begin{array}{l}\text { FAIR TO POOR: major problems in simple/complex constructions; frequent errors of } \\
\text { negation, agreement, tense, number, word order/function, articles, pronouns, prepositions } \\
\text { and/or fragments, run-ons, deletions, meanings confused or obscured }\end{array}$ \\
\hline $10-5$ & $\begin{array}{l}\text { VERY POOR: virtually no mastery of of sentence construction rules; dominated by errors; does } \\
\text { not communicate; OR not enough to evaluate }\end{array}$ \\
\hline
\end{tabular}

\section{MECHANICS}

\begin{tabular}{|l|l|}
\hline Score & Criteria \\
\hline 5 & $\begin{array}{l}\text { EXCELLENT TO VERY GOOD: demonstrates mastery of conventions; few errors of } \\
\text { spelling, punctuation, capitalization, paragraphing }\end{array}$ \\
\hline 4 & $\begin{array}{l}\text { GOOD TO AVERAGE: occasional errors of spelling, punctuation, capitalization, paragraphing } \\
\text { but meaning not obscured }\end{array}$ \\
\hline 3 & $\begin{array}{l}\text { FAIR TO POOR:frequent errors of spelling, punctuation, capitalization, paragraphing; poor } \\
\text { handwriting; meaning confused or obscured }\end{array}$ \\
\hline 2 & $\begin{array}{l}\text { VERY POOR: no mastery of conventions; dominated by the errors of spelling, punctuation, } \\
\text { capitalization, paragraphing, handwriting illegible; OR not enough to evaluate }\end{array}$ \\
\hline
\end{tabular}

